\title{
Protective effects of remifentanil preconditioning on cerebral injury during pump-assisted coronary artery bypass graft
}

\author{
T.Z. Zhang, J. Zhou, Q. Jin, Y.J. Sun, Y.G. Diao, Y.N. Zhang and Z. Zhang \\ Department of Anaesthesiology, General Hospital of Shenyang Military Region, \\ Shenyang City, Liaoning Province, China \\ Corresponding author: Z. Zhang \\ E-mail: pla201zhangzhe@163.com
}

Genet. Mol. Res. 13 (3): 7658-7665 (2014)

Received March 14, 2013

Accepted January 22, 2014

Published September 26, 2014

DOI http://dx.doi.org/10.4238/2014.September.26.3

\begin{abstract}
The protective effects of remifentanil preconditioning on serum superoxide dismutase (SOD) and malondialdehyde (MDA) during pump-assisted coronary artery bypass graft $(\mathrm{CABG})$ were investigated. Forty pump-assisted CABG patients were randomly divided into a remifentanil preconditioning group ( $\mathrm{R}$ group) and a control group ( $\mathrm{C}$ group, $\mathrm{N}=10$; normal saline). The $\mathrm{R}$ group was further divided into 3 sub-groups (R1, R2, and R3; $N=10$ per group) according to the remifentanil dose $\left(0.6,1.2\right.$, and $1.8 \mu \mathrm{g} \cdot \mathrm{kg}^{-1} \cdot \mathrm{min}^{-1}$, respectively). A venous blood sample was taken at anesthesia induction $\left(\mathrm{T}_{0}\right)$, before cardiopulmonary bypass $(\mathrm{CPB})\left(\mathrm{T}_{1}\right), \mathrm{CPB} 30 \mathrm{~min}\left(\mathrm{~T}_{2}\right)$, and after $\mathrm{CPB}\left(\mathrm{T}_{3}\right)$, and protein concentrations were measured. Patients were tested $24 \mathrm{~h}$ before and after the operation with the Mini-Mental State Examination (MMSE), and the difference was calculated. The MMSE score difference in the R3 group was lower than those of the other 3 groups $(\mathrm{P}<0.05)$. At $\mathrm{T}_{2}$ and $\mathrm{T}_{3}$, the $\mathrm{R} 3$ group showed a significant decrease in $\mathrm{S}-100 \beta$ protein and MDA and an increase in SOD $(\mathrm{P}<0.05)$ compared with the other groups, and $\mathrm{S}-100 \beta$ was negatively correlated with SOD activity $\left(\mathrm{T}_{2}: \mathrm{r}=-0.76,-0.80, \mathrm{P}<0.01 ; \mathrm{T}_{3}: \mathrm{r}=-0.795, \mathrm{P}<\right.$
\end{abstract}


$0.01)$, and was positively correlated with MDA density $\left(\mathrm{T}_{2}: \mathrm{r}=0.71, \mathrm{P}\right.$ $\left.<0.01 ; \mathrm{T}_{3}: \mathrm{r}=0.71, \mathrm{P}<0.01\right)$. In conclusion, high-dosage remifentanil preconditioning played a protective role on brain damage, possibly through inhibition of the oxidative stress response.

Key words: Extracorporeal circulation; Coronary artery bypass graft; Superoxide dismutase; Malondialdehyde; Remifentanil

\section{INTRODUCTION}

With the development of new techniques such as cardiopulmonary bypass (CPB) open-heart surgery [first performed by Gibbon in 1953 (Gibbon, 1968)], monitoring technology, cardiac surgery, cardiac surgery anesthesia, and perfusion technology, the mortality rate due to myocardial infarctions, heart failure, or fatal arrhythmia after surgery has decreased significantly, ranging from 0.5 to $5 \%$ in developed countries (Taggart et al., 1987). However, the mortality rate due to nervous system defects has increased from 7.2 to $19.6 \%$ in recent years. The incidence of central nervous system damage is 1 to $5 \%$ (Arrowsmith et al., 2000), the central nervous system dysfunction (hemiplegia, stroke) rate is 2 to $3 \%$, and the permanent central nervous system dysfunction rate is $1 \%$. Furthermore, the rate of heart surgery-related neuropsychiatric disorders is as high as 33 to $79 \%, 20 \%$ of which last for 6 months or more, and $5 \%$ of patients have permanent neuropsychiatric disorders (Borowicz et al., 1996; Nussmeier, 1996; Xie et al., 2001). Two months after surgery, approximately $20 \%$ of patients presented long-term cognitive dysfunction that was aggravated with age (Newman et al., 2001). In this sense, brain injury has seriously affected the ultimate effectiveness of open-heart bypass surgery. Therefore, investigations related to preventing brain damage in CPB have important clinical significance.

The brain damage in CPB is mainly caused by brain microthrombus formation, cerebral perfusion changes, and systemic or local inflammation. It originates from a disorder in local oxygen balance, which leads to intracellular $\mathrm{Ca}^{2+}$ overload, excitatory neurotransmitter toxicity, oxidized NO, and free radical oxygen damage. Various brain protection measures have been employed to address multiple mechanisms of brain damage, such as low temperature, drug protection, and ischemic preconditioning. Kitagawa et al. (1990) first demonstrated the neuroprotective effect of transient cerebral ischemic preconditioning in gerbils with 2 minutes of cerebral ischemia twice, which could completely prevent $5 \mathrm{~min}$ of re-ischemia-induced neuronal injury in the hippocampus $\mathrm{CAl}$ region. In recent years, an increasing number of studies have investigated the brain-protective effect of ischemic preconditioning, especially with respect to chemical preconditioning. Animal experiments have shown that remifentanil preconditioning could significantly reduce the infarct size of focal cerebral ischemia and nerve function injury after ischemia reperfusion in rats (Miao et al., 2006). However, clinical research in the cerebral protection effect of remifentanil preconditioning has not yet been reported.

In the present study, we evaluated the cerebral protection effect and possible mechanism of remifentanil preconditioning at different concentrations in coronary artery bypass grafting $(\mathrm{CABG})$ patients by $\mathrm{CPB}$. The effects were determined by evaluations of Mini-Mental State Examination (MMSE) scores and the levels of plasma S-100 $\beta$ protein, superoxide dismutase (SOD), and malondialdehyde (MDA). 


\section{MATERIAL AND METHODS}

\section{Case selection and grouping}

Forty patients (males and females) scheduled for $\mathrm{CABG}$ that were classified as American Society of Anesthesiologists (ASA) II or III were enrolled in the study. The patients ranged from 55 to 65 years of age, their heights ranged from $155-178 \mathrm{~cm}$, and their weights ranged from $50-85 \mathrm{~kg}$. There was no previous history of narrow carotid artery, nervous system diseases (transient ischemic attack, cerebral hemorrhage, cerebral infarction, brain trauma, brain tumors, etc.), diabetes, surgery, liver, or kidney dysfunction. The patients were randomly divided into 4 groups $(\mathrm{N}=10)$, including the control group (C group) and 3 remifentanil groups (R1, R2, and R3) varying in dosage.

\section{Anesthesia and CPB}

An intramuscular injection of $0.3 \mathrm{mg}$ scopolamine was administered before the anesthesia. After $1 \mathrm{~h}, 0.04 \mathrm{mg} / \mathrm{kg}$ midazolam was administered, and then a jugular vein catheter delivered local anesthesia to the jugular vein bulb; $1 \mu \mathrm{g} / \mathrm{kg}$ remifentanil, $1 \mathrm{mg} / \mathrm{kg}$ propofol, and $0.1 \mathrm{mg} / \mathrm{kg}$ pipecuronium were injected. Endotracheal intubation for mechanical ventilation was used with an $8-10 \mathrm{~mL} / \mathrm{kg}$ tidal volume, the respiratory rate was $12-16$ beats $/ \mathrm{min}$, and the carbon dioxide partial pressure of end expiration $\left(\mathrm{P}_{\mathrm{ET}} \mathrm{CO}_{2}\right)$ was $35-45 \mathrm{mmHg}(1 \mathrm{mmHg}=0.133 \mathrm{kPa})$. An intravenous injection of propofol at $6-10 \mathrm{mg} \cdot \mathrm{kg}^{-1} \cdot \mathrm{h}^{-1}$, inhalation of isoflurane with an end expiration concentration of $0.8-1.2 \%$, and intermittent injections of sufentanil and pipecuronium were administered for continuous anesthesia. The mean arterial pressure, heart rate, electrocardiogram, pulse oximetry, rectal temperature, and central venous pressure were monitored during the operation. A Stöckert-Shiley type III cardiopulmonary bypass unit (STOCKERT Co. Germany), a Xijing type II bubble oxygenator (China Guangdong Dongguan Kewei Medical Instrument Co.), and an arterial micro-plug filtration device (Guangdong Shunde Derun Medical Instrument Chemical Engineering Co. China) were used for the CPB, and the perfusion pressure was maintained at 50-80 $\mathrm{mmHg}$. During the $\mathrm{CPB}$, moderate hemodilution was administered with $25-30 \%$ hematocrit (Hct), and the rectal temperature was maintained at $35^{\circ}-37^{\circ} \mathrm{C}$. A steady-state was applied in CPB, with an arterial oxygen pressure of $250 \mathrm{mmHg}$.

\section{Test method}

Remifentanil $\left(0.6,1.2\right.$, and $\left.1.8 \mu \mathrm{g} \cdot \mathrm{kg}^{-1} \cdot \mathrm{min}^{-1}\right)$ was respectively administered by intravenous infusion in the R1, R2, and R3 groups 30 min after anesthesia induction, and the remifentanil preconditioning was accomplished by intravenous infusion for $5 \mathrm{~min}$, which was repeated three times at $5 \mathrm{~min}$ intervals. After the preconditioning, the operation was initiated. The $\mathrm{C}$ group was administered an equivalent concentration of normal saline instead of remifentanil.

\section{Specimen collection and determination}

The right internal jugular vein was punctured, which progressed toward the head, and the catheter was placed in the jugular vein bulb at the cutting-edge position corresponding 
to the external auditory canal. Three milliliters venous blood sample was taken at anesthesia induction $\left(\mathrm{T}_{0}\right)$, before CPB $\left(\mathrm{T}_{1}\right), 30 \mathrm{~min}$ CPB $\left(\mathrm{T}_{2}\right)$, and end CPB $\left(\mathrm{T}_{3}\right)$, centrifuged at 5000 rpm for $10 \mathrm{~min}$, and separated plasma was preserved at $-70^{\circ} \mathrm{C}$. The plasma concentration of the S-100 $\beta$ protein was detected by enzyme-linked immunorsorbent assay (ELISA); ELISA kits were purchased from Biokey (USA). The plasma SOD and MDA activities were detected using the colorimetric method with detection kits purchased from the Nanjing Jiancheng Institute of Biotechnology. The measured data were corrected with the following formula: correction value $=$ measured value $\times \mathrm{T}_{0}$ Hct $/$ measured Hct.

The MMSE, a neuropsychological testing scale, was chosen to evaluate the cognitive function status of patients. Patients were tested $24 \mathrm{~h}$ before and after the operation in a double-blind manner, and the difference in scores was calculated (preoperative MMSE score - postoperative MMSE score).

\section{Statistical analysis}

SPSS 10.0 was used for the statistical analysis. Data are reported as means \pm standard deviations, and differences among groups were compared by analysis of variance. The correlation between S-100 $\beta$ protein and SOD and MDA levels was determined by linear correlation analysis. A value of $\mathrm{P}<0.05$ was considered to indicate a statistically significant difference.

\section{RESULTS}

Subjects enrolled in the four groups did not show significant statistical differences in aspects of general state, operation time, CPB time, or blockage time $(\mathrm{P}>0.05)($ Table 1).

\begin{tabular}{|c|c|c|c|c|c|c|c|c|}
\hline Group & $\begin{array}{l}\text { Gender ratio } \\
\text { (male/female) }\end{array}$ & $\begin{array}{l}\text { Age } \\
\text { (year) }\end{array}$ & $\begin{array}{l}\text { Body weight } \\
\text { (kg) }\end{array}$ & $\begin{array}{l}\text { Body height } \\
(\mathrm{cm})\end{array}$ & $\begin{array}{c}\text { Surface area } \\
\left(\mathrm{m}^{2}\right)\end{array}$ & $\begin{array}{l}\text { Operation time } \\
\text { (h) }\end{array}$ & $\begin{array}{l}\text { CPB time } \\
\quad(\min )\end{array}$ & $\begin{array}{l}\text { Blockage time } \\
(\mathrm{min})\end{array}$ \\
\hline $\mathrm{C}$ group & $8 / 2$ & $63 \pm 9$ & $69 \pm 9$ & $167 \pm 7$ & $1.67 \pm 0.15$ & $3.7 \pm 0.9$ & $49 \pm 9$ & $35 \pm 7$ \\
\hline $\mathrm{R}_{1}$ group & $8 / 2$ & $61 \pm 9$ & $68 \pm 6$ & $167 \pm 9$ & $1.68 \pm 0.12$ & $3.9 \pm 0.4$ & $51 \pm 9$ & $34 \pm 7$ \\
\hline $\mathrm{R}_{2}$ group & $8 / 2$ & $65 \pm 8$ & $75 \pm 13$ & $169 \pm 8$ & $1.66 \pm 0.12$ & $3.6 \pm 0.7$ & $49 \pm 11$ & $36 \pm 8$ \\
\hline $\mathrm{R}_{3}$ group & $7 / 3$ & $63 \pm 7$ & $68 \pm 10$ & $166 \pm 7$ & $1.67 \pm 0.14$ & $3.5 \pm 0.4$ & $50 \pm 11$ & $35 \pm 7$ \\
\hline
\end{tabular}

Data are reported as means \pm SD.

The operation was successfully completed in all the 40 patients with no postoperative deaths. There were no significant differences among groups in the MMSE score $24 \mathrm{~h}$ before or after the operation. However, the MMSE score difference was lower in the R3 group compared to the other three groups $(\mathrm{P}<0.05)$, as shown in Table 2 .

Table 2. Mini-Mental State Examination score $(\mathrm{N}=10)$.

\begin{tabular}{lccc}
\hline & 24 h before operation & 24 h after operation & Difference \\
\hline C group & $24.6 \pm 3.4$ & $22.0 \pm 3.1$ & $2.6 \pm 1.7$ \\
$\mathrm{R}_{1}$ group & $24.8 \pm 3.4$ & $22.5 \pm 4.3$ & $2.3 \pm 1.6$ \\
$\mathrm{R}_{2}$ group & $25.9 \pm 3.4$ & $23.3 \pm 4.3$ & $2.6 \pm 1.8$ \\
$\mathrm{R}_{3}$ group & $24.4 \pm 1.6$ & $24.2 \pm 1.6$ & $0.2 \pm 1.9^{*}$ \\
\hline
\end{tabular}

$* \mathrm{P}<0.05$ vs $\mathrm{C}$ group. Data are reported as means $\pm \mathrm{SD}$. 
There were no significant differences among the groups in S-100 $\beta$ protein, SOD, and MDA levels at $T_{0}$ in patients within the normal range $(P>0.05)$. At $T_{1}, T_{2}$, and $T_{3}$, all groups had significantly higher concentration of S-100 $\beta$ protein and MDA and lower activity of SOD compared with the $\mathrm{T}_{0}$ time point $(\mathrm{P}<0.05$ or $\mathrm{P}<0.01)$. At $\mathrm{T}_{2}$ and $\mathrm{T}_{3}$, the $\mathrm{R} 3$ group showed a significant decrease in S-100 $\beta$ protein and MDA levels and an increase in SOD levels $(\mathrm{P}<$ 0.05 ) compared with the $\mathrm{C}$ group; no such statistical differences were observed in the $\mathrm{R} 1$ and $R 2$ groups $(\mathrm{P}>0.05)$ (Table 3$)$. At $\mathrm{T}_{2}$ and $\mathrm{T}_{3}$, the $\mathrm{S}-100 \beta$ protein concentration was negatively correlated with SOD activity $(\mathrm{r}=-0.76,-0.80, \mathrm{P}<0.01)$ and was positively correlated with MDA density $(r=0.71, \mathrm{P}<0.01)$.

\begin{tabular}{|c|c|c|c|c|c|}
\hline Index & Group & $\mathrm{T}_{0}$ & $\mathrm{~T}_{1}$ & $\mathrm{~T}_{2}$ & $\mathrm{~T}_{3}$ \\
\hline \multirow[t]{4}{*}{$\mathrm{S}-100 \beta$ protein $(\mu \mathrm{g} / \mathrm{L})$} & $\mathrm{C}$ group & $0.104 \pm 0.003$ & $0.250 \pm 0.061^{*}$ & $1.289 \pm 0.194^{\#}$ & $1.417 \pm 0.193^{\#}$ \\
\hline & $\mathrm{R}_{1}$ group & $0.096 \pm 0.003$ & $0.213 \pm 0.043^{*}$ & $1.244 \pm 0.142^{\#}$ & $1.346 \pm 0.144^{\#}$ \\
\hline & $\mathrm{R}_{2}$ group & $0.102 \pm 0.004$ & $0.232 \pm 0.091^{*}$ & $1.184 \pm 0.183^{\#}$ & $1.333 \pm 0.171^{\#}$ \\
\hline & $\mathrm{R}_{3}$ group & $0.100 \pm 0.003$ & $0.246 \pm 0.046^{*}$ & $0.918 \pm 0.187^{\# \Delta}$ & $1.079 \pm 0.150^{\# \Delta}$ \\
\hline \multirow[t]{4}{*}{$\mathrm{SOD}(\mathrm{U} / \mathrm{mL})$} & $\mathrm{C}$ group & $111 \pm 13$ & $101 \pm 9^{*}$ & $80 \pm 5^{\#}$ & $69 \pm 7^{\#}$ \\
\hline & $R_{1}$ group & $111 \pm 13$ & $104 \pm 15^{*}$ & $81 \pm 7^{\#}$ & $73 \pm 7^{\#}$ \\
\hline & $\mathrm{R}_{2}$ group & $110 \pm 15$ & $101 \pm 14^{*}$ & $82 \pm 10^{\#}$ & $74 \pm 9^{\#}$ \\
\hline & $\mathrm{R}_{3}$ group & $106 \pm 10$ & $100 \pm 9^{*}$ & $90 \pm 6^{\# \Delta}$ & $83 \pm 8^{\# \Delta}$ \\
\hline \multirow[t]{4}{*}{$\operatorname{MDA}(\mathrm{nmol} / \mathrm{mL})$} & $\mathrm{C}$ group & $4.8 \pm 1.0$ & $6.5 \pm 1.4^{*}$ & $10.8 \pm 1.7^{\#}$ & $12.5 \pm 1.8^{\#}$ \\
\hline & $\mathrm{R}_{1}$ group & $4.5 \pm 1.2$ & $6.3 \pm 1.8^{*}$ & $10.9 \pm 1.7^{\#}$ & $12.4 \pm 1.8^{\#}$ \\
\hline & $\mathrm{R}_{2}$ group & $4.8 \pm 1.3$ & $6.4 \pm 1.3 *$ & $10.6 \pm 1.8^{\#}$ & $12.8 \pm 1.7^{\#}$ \\
\hline & $\mathrm{R}_{3}$ group & $4.7 \pm 1.0$ & $6.3 \pm 1.2^{*}$ & $8.7 \pm 1.5^{\# \Delta}$ & $10.4 \pm 1.4^{\# \Delta}$ \\
\hline
\end{tabular}

$* \mathrm{P}<0.05,{ }^{\#} \mathrm{P}<0.01 v s \mathrm{~T}_{0}$ time point, ${ }^{\Delta} \mathrm{P}<0.05$ vs group $\mathrm{C}$. Data are reported as means $\pm \mathrm{SD}$.

\section{DISCUSSION}

There are currently several tools available for clinical evaluations of cognitive function, and the MMSE is the most widely applied. MMSE assesses 11 test items including location and orientation, immediate memory, attention and calculation ability, recent memory, language, language repeat, object naming, language comprehension, reading comprehension, writing, and graphic painting. MMSE is commonly used for the examination and diagnosis of intelligence state and cognitive impairment degree in people over 65 years old with suspected cognitive impairment, including normal subjects and patients with various mental illnesses. Tang et al. (1999) reported $84.6 \%$ sensitivity and $96.1 \%$ specificity in the evaluation of cognitive impairment by MMSE. In the present study, the MMSE score was applied for the evaluation of cognitive function before and after CPB. Previous studies have shown that brain damage induced by CPB appeared as short-term cognitive impairment and decreased scores of neurological function after the operation (Murkin, 2005; Taggart and Westaby, 2001). Our study showed that the MMSE score difference was significantly lower in the group administered with a high dose of remifentanil preconditioning $\left(1.8 \mu \mathrm{g} \cdot \mathrm{kg}^{-1} \cdot \mathrm{min}^{-1}\right)$ compared to the other 3 groups $(\mathrm{P}<0.05)$, which suggested that high-dose remifentanil preconditioning could play a role in brain protection, thus palliating brain damage.

Of the many biochemical markers that can be used to reflect brain injury, the S- $100 \beta$ protein is considered a particularly useful indicator of early brain injury. The S-100 $\beta$ protein is a dimer formed from the $\alpha$ and $\beta$ subunits; the $\beta \beta$-subtype presents only in the central glial 
cells, astrocytes, most sensory neurons of the brain stem, and cerebellar nucleus, and the $\alpha \beta$ subtype presents in glial cells but not in Schwann cells. Therefore, the S-100 $\beta$ protein concentration in blood and cerebrospinal fluid can be used to evaluate the specificity of brain injury. The S-100 $\beta$ protein is an extremely large molecule, which cannot pass the blood-brain barrier under normal circumstances. There is an obvious concentration difference in S-100 $\beta$ between the cerebrospinal fluid and the blood. Therefore, a high expression level of S-100 $\beta$ in the blood indicates not only brain injury, but also increased permeability of the blood-brain barrier. The $\mathrm{S}-100 \beta$ protein level in plasma is not influenced by hemolysis, hypothermia, heparin, and other narcotic drugs (Ozatik et al., 2002). Plasma concentrations of the S-100 $\beta$ protein exceeding $0.5 \mu \mathrm{g} / \mathrm{L}$ is the diagnosis criterion for brain injury (Jönsson et al., 2000). The biological half-life of the plasma S-100 $\beta$ protein is 25 min (Parolari et al., 2000); thus, moderate renal dysfunction does not affect its excretion. In the present study, the plasma S-100 $\beta$ protein concentration exceeded $0.5 \mu \mathrm{g} / \mathrm{L}$ in patients, indicating brain damage after CPB.

The mechanism of brain injury induced by CPB is complicated; therefore, a variety of measures is employed for brain protection. Currently, the most common cerebral protection methods and techniques include low temperature, microthrombus filter, membrane oxygenator, and heparin-coated pipes of $\mathrm{CPB}$, among others. However, brain protection with ischemic and pharmacological preconditioning is receiving increasing attention. Previous studies have confirmed that repeated short-term, sub-lethal ischemia played a protective role for subsequent ischemia/reperfusion injury, but that ischemia of longer durations or exceeding the tolerance threshold could increase the ischemic injury. A previous study showed that hippocampal neuronal damage appeared after ischemic preconditioning through bilateral common carotid artery ligation for 3 or 4 min with no protection for subsequent fatal ischemia. Further, 8 min ischemic preconditioning was shown to cause ischemic necrosis of hippocampal neurons, whereas $6 \mathrm{~min}$ ischemic preconditioning showed not only no neuronal damage, but also a significant protective effect against the fatal cerebral ischemia that follows (Wu et al., 2002). In fact, it is very difficult to determine the ideal ischemia time and interval time of ischemic preconditioning that will result in no damage of nerve tissue while producing a protective effect in a clinical setting. Therefore, pharmacological preconditioning has received increasing attention in recent years.

Opioid receptor agonists are commonly used for perioperative analgesia with general clinical applications. If these types of drugs play a role in brain protection, a new avenue will be developed for the prevention of brain damage by pharmacological preconditioning. Lim et al. (2004) performed pharmacological preconditioning by using different concentrations of morphine in rat cerebellar brain slices in vitro and found that the number of surviving neurons in brain slices was increased in a dose-dependent manner, indicating an obvious neuroprotective effect of $0.3 \mu \mathrm{M}$ morphine with a $0.3 \mu \mathrm{M}$ ceiling-effect concentration. Its protective effect could be antagonized by a $\delta 1$ opioid receptor antagonist. Internal studies (Zheng et al., 2005 ) showed that a high concentration of fentanyl preconditioning played a protective role in rat brain slices with oxygen-glucose deprivation; one possible mechanism suggested was the reduction of calcium influx of brain cells. However, due to the longer distribution and elimination half-life of morphine and fentanyl, it is difficult to determine the direct effect or the preconditioning effect of opioid receptor agonists on brain protection (Schultz et al., 1997).

Remifentanil is a new opioid drug with the following characteristics: rapid onset, small distribution volume, fast clearance rate, short blood-brain equilibration time, $\mathrm{T}_{1 / 2} \mathrm{Keo}$ (half-time value of plasma concentration and effect concentration equilibrium) of $1 \pm 1 \mathrm{~min}$, 
and $1.5 \mathrm{~min}$ to the peak effect by a single dose. The $\mathrm{t} 1 / 2 \mathrm{cs}$ (half-life of time-amount correlation) of remifentanil is 3-5 min, which is independent of the continuous infusion time, and remifentanil is a narcotic analgesic of high performance that is immediate and short acting (Bi et al., 2003). Therefore, remifentanil was administered in this study of brain protection induced by preconditioning, which could exclude the direct effect of opioid receptor agonists. Animal experiments (Miao et al., 2006) showed that $0.6 \mu \mathrm{g} \cdot \mathrm{kg}^{-1} \cdot \mathrm{min}^{-1}$ remifentanil played a cerebral protection role. Zhang et al. (2004) confirmed that remifentanil preconditioning played a protection role for myocardial ischemia/reperfusion injury at $0.6 \mu \mathrm{g} \cdot \mathrm{kg}^{-1} \cdot \mathrm{min}^{-1}$; its protective effect showed a trend of dose-dependency, and $6 \mu \mathrm{g} \cdot \mathrm{kg}^{-1} \cdot \mathrm{min}^{-1}$ was the most effective dosage. In the present study, based on the literature and clinical medication range (0.1-2 $\mu \mathrm{g} \cdot \mathrm{kg}^{-1} \cdot \mathrm{min}^{-1}$ ), we selected 3 dosages to explore remifentanil protection in the analgesic dose range: $0.6,1.2$, and $1.8 \mu \mathrm{g} \cdot \mathrm{kg}^{-1} \cdot \mathrm{min}^{-1}$. Results showed that the S-100 $\beta$ protein concentration increased during $\mathrm{CPB}$, exceeding $0.5 \mu \mathrm{g} / \mathrm{L}$, which indicated some degree of brain damage in all CPB patients. The plasma concentrations of the S-100 $\beta$ protein decreased only in the 1.8 $\mu \mathrm{g} \cdot \mathrm{kg}^{-1} \cdot \mathrm{min}^{-1}$ remifentanil preconditioning group, indicating that the protection of remifentanil preconditioning occurs in a dose-dependent manner.

The mechanism of CPB-induced brain damage is relatively complex, in which free radical-induced lipid peroxidation plays an important role. Oxygen radicals can attack proteins, nucleic acids, and unsaturated fatty acids on the membrane, causing cell damage and cell death. Oxygen free radicals can activate inflammatory cytokines and related enzymes, thus triggering the inflammatory response, which leads to more free radicals, creating a vicious cycle. Compared with other tissues, nerve tissue has a higher metabolic rate of oxygen contains rich, high-density unsaturated fatty acids, is $\mathrm{Fe}^{2+}$-rich, and relies on complete synaptic transmission and weak anti-oxidation capacity. Therefore, the brain is particularly sensitive to oxygen free radical damage and is vulnerable to free radical-mediated damage (Evans, 1993; Hans et al., 1996).

SOD, an important oxygen free radical scavenger, clears free radicals by catalyzing superoxide anions for disproportionation reactions, and plays a protective role in tissues and cells by enhancing the regulatory function of hydrogen peroxide. MDA is a final metabolite of lipid peroxidation from biofilm polyunsaturated fatty acids induced by free radicals, and therefore reflects the activity of free radicals and the degree of cell damage. Thus, SOD and MDA may reflect the ability of scavenging oxygen free radicals.

This study showed that plasma SOD activity decreased and the MDA concentration increased during $\mathrm{CPB}$, indicating $\mathrm{CPB}$-induced lipid peroxidation in the brain tissue. The remifentanil preconditioning at $1.8 \mu \mathrm{g} \cdot \mathrm{kg}^{-1} \cdot \mathrm{min}^{-1}$ increased plasma SOD activity and decreased the MDA concentration, and the S-100 $\beta$ protein was negatively correlated with SOD and positively correlated with MDA, suggesting that the brain protection effect of remifentanil preconditioning occurred by inhibiting lipid peroxidation. These results are in accordance with those of Sun et al. (2009). The specific mechanism needs to be further investigated, but may be related to the opioid receptor. Kato et al. (2000) observed fentanyl protection for myocardial ischemic damage in rats, and confirmed that fentanyl activated the protein kinase C signal transduction pathway via the opioid receptor, which caused ATP-sensitive potassium channels to open, thereby palliating myocardial calcium overload. Moreover, $\mathrm{Wu}$ et al. (2009) confirmed that sufentanyl preconditioning inhibited lipid peroxidation by the effect of the opioid receptor. 
In summary, remifentanil preconditioning at $1.8 \mu \mathrm{g} \cdot \mathrm{kg}^{-1} \cdot \mathrm{min}^{-1}$ could relieve brain damage induced by CPB in CABP patients, and the mechanism may be related with inhibition of brain lipid peroxidation.

\section{REFERENCES}

Arrowsmith JE, Grocott HP, Reves JG and Newman MF (2000). Central nervous system complications of cardiac surgery. Br. J. Anaesth. 84: 378-393.

Bi XL, You QD and Chen L (2003). Spectral data and structural analysis of remifentanil hydrochloride. Progr. Pharmac. Sci. 26: 360-362.

Borowicz LM, Goldsborough MA, Selnes OA and McKhann GM (1996). Neuropsychologic change after cardiac surgery: a critical review. J. Cardiothorac. Vasc. Anesth. 10: 105-111.

Evans PH (1993). Free radicals in brain metabolism and pathology. Br. Med. Bull. 49: 577-587.

Gibbon JH Jr (1968). Development of the artificial heart and lung extracorporeal blood circuit. JAMA 206: 1983-1986.

Hans P, Deby C, Deby-Dupont G, Vrijens B, et al. (1996). Effect of propofol on in vitro lipid peroxidation induced by different free radical generating systems: a comparison with vitamin E. J. Neurosurg. Anesthesiol. 8: 154-158.

Jönsson H, Johnsson P, Hoglund P, Alling C, et al. (2000). Elimination of S100B and renal function after cardiac surgery. J. Cardiothorac. Vasc. Anesth. 14: 698-701.

Kato R, Ross S and Foëx P (2000). Fentanyl protects the heart against ischaemic injury via opioid receptors, adenosine A1 receptors and KATP channel linked mechanisms in rats. Br. J. Anaesth. 84: 204-214.

Kitagawa K, Matsumoto M, Tagaya M, Hata R, et al. (1990). 'Ischemic tolerance' phenomenon found in the brain. Brain Res. 528: 21-24.

Lim YJ, Zheng S and Zuo Z (2004). Morphine preconditions Purkinje cells against cell death under in vitro simulated ischemia-reperfusion conditions. Anesthesiology 100: 562-568.

Miao XR, Xiong L and Wang Q (2006). Remifentanil preconditioning induces protection against focal cerebral ischemiareperfusion injury in rats. J. Clin. Anesthesiol. 4: 277-279.

Murkin JM (2005). Neurocognitive outcomes: the year in review. Curr. Opin. Anaesthesiol. 18: 57-62.

Newman MF, Kirchner JL, Phillips-Bute B, Gaver V, et al. (2001). Longitudinal assessment of neurocognitive function after coronary-artery bypass surgery. N. Engl. J. Med. 344: 395-402.

Nussmeier NA (1996). Adverse neurologic events: risks of intracardiac versus extracardiac surgery. J. Cardiothorac. Vasc. Anesth. 10: 31-37.

Ozatik MA, Tarcan O, Kale A, Askin GA, et al. (2002). Do S100beta protein level increases due to inflammation during cardiopulmonary bypass occur without any neurological deficit? Perfusion 17: 335-338.

Parolari A, Alamanni F, Naliato M, Spirito R, et al. (2000). Adult cardiac surgery outcomes: role of the pump type. Eur. J. Cardiothorac. Surg. 18: 575-582.

Schultz JJ, Hsu AK and Gross GJ (1997). Ischemic preconditioning and morphine-induced cardioprotection involve the delta (delta)-opioid receptor in the intact rat heart. J. Mol. Cell Cardiol. 29: 2187-2195.

Sun YM, Ge YH and Yang LQ (2009). Remifentanil preconditioning attenuates hepatic ischemia and reperfusion injury in rats. Acad. J. Second Mil. Med. Univ. 30: 659-662.

Taggart DP and Westaby S (2001). Neurological and cognitive disorders after coronary artery bypass grafting. Curr. Opin. Cardiol. 16: 271-276.

Taggart DP, Reece IJ and Wheatley DJ (1987). Cerebral deficit after elective cardiac surgery. Lancet 1: 47.

Tang M, Zou XY and Han HY (1999). Application of CMMSE in subjects aged 55 or above from different districts of Chengdu. Chin. Mental Health J. 4: 200-202.

Wu CR, Zhao JY and Wu CT (2002). Experimental study on the protective effects of ischemic preconditioning on brain ischemia-reperfusion injury in mice. Chin. J. Anesthesiol. 9: 42-46.

Wu CN, Tu WF and Jiang P (2009). Effects of sulfentanyl on lipoperoxidation of myocardial tissue after thermal trauma in rats. Guangdong Med. J. 30: 169-170.

Xie LG, Hu XQ and Wu XM (2001). Morbidity of neuropsychiatric nisorder in the early postoperative period after cardiovascular surgery. Chin. Circulation J. 16: 369-371.

Zhang Y, Irwin MG and Wong TM (2004). Remifentanil preconditioning protects against ischemic injury in the intact rat heart. Anesthesiology 101: 918-923.

Zheng YJ, Wang XG, Wu XJ, Chen HZ, et al. (2005). Protective effects of high concentration fentanyl on brain slice injury induced by oxygen glucose deprivation. Chin. Pharmacol. Bull. 21: 1246-1250. 